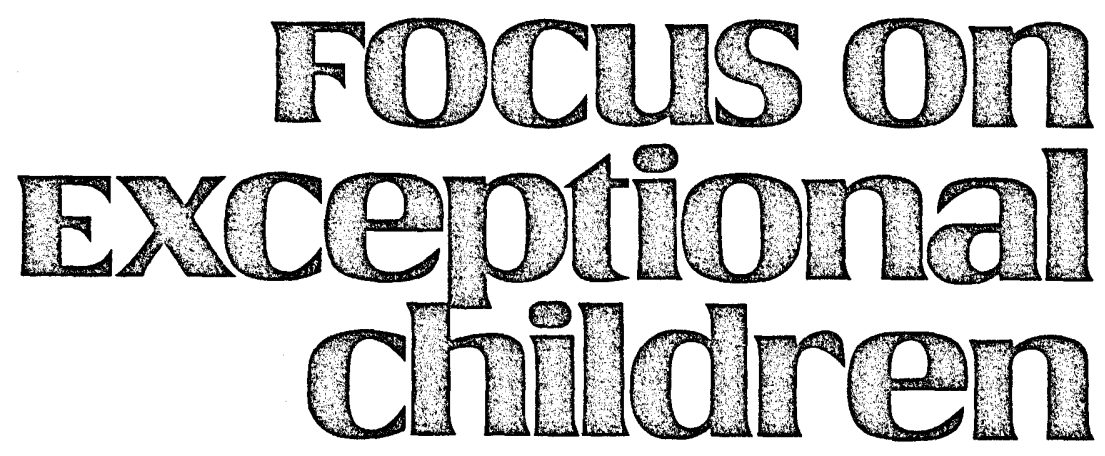

\title{
Implications of Social and Cultural Differences for Special Education With Specific Recommendations
}

\author{
Ellen A. Brantlinger and Samuel L. Guskin
}

Programs for multicultural, nonsexist, and handicap awareness share a number of common characteristics and goals. All three focus on diminishing the stereotypes of their respective groups and on increasing their power. Their goals are to enhance academic performance and general student competence and to improve interaction among diverse groups of students, enabling these students to work together for a future they all share.

\section{DEFINITIONS AND IMPLICATIONS}

Smith (1983) explores the similarities and intertwinings of the "isms" (racism, sexism, heterosexism) as a productive way of examining prejudice and showing how systems of oppression interconnect. Holding negative stereotypes of low-income people and of handicapped groups can fittingly be added to Smith's list. These minorities constitute political categories representing persons who, for no reason other than some biological, physical (ethnocultural or social-psychological) difference, are negated, denied, discriminated against, and oppressed (Tinney, 1983).

These groups are defined as minorities not because they are few in numbers (for example, females in fact outnumber males), but because they are politically excluded from proportionate roles and responsibilities in the major institutions of power. Too, they receive less than their share of goods, services, values, rewards, power, prestige, and prerogatives (Tinney, 1983). All are groups that majority, or dominant, groups define as deviant, difficult, inferior, or wrong (Lorde, 1983). Ogbu (1974) uses the term "subordinate subgroups" to describe oppressed minorities.

Belief in the inherent superiority of one pattern over others justifies the powerful group's right to dominance (Lorde, 1983). Competence, then, is not so much a matter of individual ability as it is a matter of who has the power (such as public school teachers) to define and judge competence (Burnett, 1976). Cultural attributes are determined by dominant classes in a capitalist society and are transmitted differentially to school children, reproducing in school the inequitable power relations characteristic of the larger society (Giroux, 1983). In fact, Berman (1984) asserts, school may be the most visible arena in which capitalist hegemony is disseminated to a captured clientele. Thus, the public school, being a mechanism for cultural transmission, is boundary maintaining rather than boundary breaking, in structuring ranked social groups (Singleton, 1974).

Ellen Brantlinger and Samuel Guskin are affiliated with the Special Education Department, Indiana University. 


\section{Forms of Discrimination}

Tinney (1983) has distinguished three different levels of discrimination: institutional, collective, and individual. Institutional discrimination prevents equal participation in associations or the bestowal of equal benefits by those associations. Institutional discrimination (i.e., educational, social, legal) has been rampant regarding handicapped individuals. Until 1975, handicapped children could be legally excluded from the public school-an institution requiring mandatory attendance for nonhandicapped individuals. Laws requiring involuntary sterilization or incarceration of handicapped people were in effect in most states during this century. Rights to sexual behavior, marriage, and parenthood have been denied handicapped people simply because they had been classified as handicapped.

Regarding present policies, McKnight (1982), for example, questions the existence of a "disorder" with learning disabled students, claiming that the label is instead an effort to justify the school's failure to educate a segment of the school population. Similarly, rights of racial or ethnic

\section{Focus on
Exceptional children}

FOCUS ON EXCEPTIONAL CHILDREN (ISSN0015-511X) (USPS 203-360) is published monthly except June, July, and August as a service to teachers, special educators, curriculum specialists, administrators, and those concerned with the special education of exceptional children. This journal is abstracted and indexed in Exceptional Child Education Resources, and is also available in microform from Xerox University Microfilm. Ann Arbor, Michigan. Subscription rates, $\$ 18.00$ per year. Copyright $\odot 1985$. Love Publishing Company. All rights reserved. Reproduction in whole or part without written permission is prohibited. Printed in the United States of America. Second class postage is paid at Denver, Colorado.

POSTMASTER: Send address changes to:

$$
\begin{aligned}
& \text { Love Publishing Company } \\
& \text { Executive and Editorial Office } \\
& 1777 \text { South Bellaire Street } \\
& \text { Denver, Colorado } 80222 \\
& \text { Telephone (303) 757-2579 } \\
& \text { EDITORIAL BOARD }
\end{aligned}
$$

Edward L. Meyen University of Kansas

Glenn A. Vergason Georgia State University

Richard J. Whelan

University of Kansas Medical Center
Stanley F. Love Publisher
Carolyn Acheson Senior Editor minorities related to schooling, as well as other domains of life, have been-and in many ways still are-restricted. Thus, "Rights have been and remain the prerogative of only one group consistently." (Tinney, 1983, p. 5).

Collective discrimination refers to "those discriminations which result from collective norms, values, and mores that work within society to legitimize oppressions" (Tinney, 1983 , p. 5). For example, there is a general, or collective, denial of minority culture. White, Anglo-Saxon, middleclass values predominate in school, and cultural traditions of minority groups are perceived as obstructions. Minority students are expected to renounce the unique aspects of themselves and assimilate to the dominant culture in school. Most school evaluation systems are set up so that only one group-academically-advanced students-can really succeed. Collective (i.e., normed), very limited interpretations exist regarding intelligence, achievement, and success in school, and these interpretations favor the dominant majority.

Individual discrimination, or personal prejudice, based on stereotypes and misinformation is the easiest form of discrimination to notice and combat, in Tinney's (1983) opinion. Perhaps most of the present effort to eradicate discrimination focuses on individual discrimination in the form of multicultural, nonsexist, and handicap-sensitive teacher training.

\section{Discrimination in Education}

Among the most pressing challenges of public education is to provide quality education to children of various personal characteristics in integrated settings. Oden (1976) contends that school desegregation and mainstreaming are the most urgent moral imperatives facing the American people. In addition to between-school segregation, such as racial segregation, attention has been focused on within-school segregation, such as tracking students according to ability or providing separate special education services.

Numerous books on the subject of racial desegregation have been published in the past decade (e.g., Crain, Mahard, \& Narot, 1982; Orfield, 1978; Patchen, 1982; Rist, 1979; St. John, 1975; Schofield, 1982). At the same time, mainstreaming of handicapped children has been the focus of attention of many special educators (e.g., Gottlieb, 1982; Jones \& Wilderson, 1976; MacMillan, 1976; Polloway, 1984). Although social class desegregation has not been a widely acknowledged goal, many have written about the influence of social class membership on schooling (e.g., Anyon, 1980; Apple, 1982; Bowles \& Gintis, 1976; Brantlinger, 1985a; Jenks, 1972; Lightfoot, 1981; Sieber, 1982). Social class segregation in education, in fact, is intimately and intricately related to racial segregation, special class segregation, and tracking segregation. 


\section{Intelligence and Achievement Scores}

It has long been documented that low-income and minority students' IQ and achievement scores are lower than high-income and majority children. Ramey and Campbell (1979) claim that social class has a pronounced effect on scores on developmental tests. Children of higher socioeconomic classes show progressive gains in their rate of development beginning in infancy, while lower SES children show progressive decline relative to norms. In a study of approximately 26,000 black and white 4-year-olds, Broman, Nichols, and Kennedy (1975) found that SES was the best single predictor of IQ. Kushlick and Blunder (1974) claim that the relationship between social class and retardation is so strong that no parents of higher socioeconomic groups have children with IQs of less than 80 unless they have a pathological condition, as demonstrated cross-culturally by a series of epidemiological studies. Mare (1981) projects that the dependence of educational attainment on social origins will continue to increase.

Racial and ethnic status are similarly correlated with achievement and cognitive measures. Yet, Levine, Kukuk, and Meyer (1979) wrote that the correlation of race and achievement does not mean that racial composition is independently related to achievement apart from SES. Results of their analysis indicated that racial composition generally added nothing to the prediction. Thus, when SES is controlled, racial differences in test results tend to disappear.

Even when IQ is held constant, achievement scores fluctuate according to race and social class. Gordon (1976) reported on a study involving 1,102 Chicago-area fifth and sixth graders who were aggregated into seven cohorts of approximately equal IQ scores (95-104.9); whites scored higher on achievement tests than blacks of the same sex and race. Gordon concluded that "overachievement" and "underachievement" among children with similar IQ scores were consistently related to race and class.

\section{Placement and Services}

Proportionately more blacks and other minority children are placed in special classes (Anderson \& Anderson, 1983; Argulewicz, 1983; Educational Testing Service, 1980; Ford, Mongon, \& Whelan, 1982; Pink, 1982; Polloway \& Smith, 1983; Ysseldyke, Algozzine, \& Richey, 1982). Linguistically different children are even more disproportionately represented (Aguirre, 1979; Argulewicz, 1983; Bernal, 1983; Ochoa, Pacheco, \& Omark, 1983; Wright \& Santa Cruz, 1983). Bernal (1983) maintains that many "normal" LEP (Limited-English proficient) children are placed in special classes in systems that have resisted bilingual programming. Gerber (1984) expressed concern about erroneous classification and inequitable treatment of children labeled as handicapped in the educational system. Algozzine, Ysseldyke, and Christenson (1983) found that between 1977 and 1980 the rate of new cases of children referred and placed with special education services (i.e., incidence) increased at a rate of $3 \%$ per year.

Moran (1984) recommends that special, remedial, and compensatory education join together to claim a place for low achievers in the mainstream. She feels that separate administrations, teachers, materials, and accountability work against chances of integration. Gardner (1982) concurs, stating that special education has been diverting too much staff time toward determining which category of exceptionality is appropriate to serve low-achieving students.

Special education has been perceived as a special case of tracking (Madden \& Slavin, 1983). Parents tend to accept professional judgment as legitimate authority and assume they are doing what is best for their children. Parents of children in lower tracks have been led to believe that their children are less capable and less intelligent than other children. Drummond (1982) maintains that to suggest that a handicap, such as mental illness, resides solely within the individual is the power elite's lie. Oden (1976) states that special education in isolation is a vicious form of segregation with negative effects on children. Such a statement sounds remarkably similar to one made by Charles. Sumner before the Massachusetts Supreme Court in 1849: "Segregation injures the child who is white as well as the minority child . . . their hearts, while yet tender with childhood, are necessarily hardened by this conduct, and their subsequent lives, perhaps, bear enduring testimony to this legalized uncharitableness" (Harris, 1978, p. 53).

In accordance with most desegregation and mainstreaming ideologies, the position taken in this article is that inclusion of diverse children in schools and classrooms is desirable. Like Crosland (1974), we argue for a sense of community and social cohesion that may result in a nation composed of people who understand and care about each other.

\section{RECOMMENDATIONS FOR INSTRUCTION OF HETEROGENEOUS GROUPS}

\section{Class Size}

Glass (1980) recommends that federal funds be spent for extra teachers to reduce teacher/pupil ratios and permit mixed groupings of high, average, and low achievers in smaller classes instead of segregating special education students for special services. Clark, Lotto, and McCarthy (1980) summarized research on urban schools, and among their recommendations was to reduce teacher/pupil ratios. But Longo (1982) cautions that merely reducing class size will not necessarily improve the academic rate of low achievers. Other facilitating strategies have to be adopted. 


\section{Individualized Instruction}

According to Longo (1982), differentiated or individualized instruction is a necessary strategy for teaching diverse groups. His plan for integration is to: (1) retrain and reorient teachers and administrators; (2) provide direct support to teachers as they initiate integration; (3) allow longterm planning by building teams; and (4) encourage a variety of instructional mechanisms and environments (pp. 164, 176).

Similarly, Wang (1976) developed the Individually Prescribed Instruction program, which allows students choices of time and sequence for doing prescribed activities independently. A later report (Reynolds \& Wang, 1983) described the Adaptive Learning Environment Model (ALEM), based on a systems approach to program development. ALEM includes a highly structured, hierarchically organized prescriptive environment, maximization of use of time and classroom resources, multi-age grouping and instructional teaming support systems, a systematic staff development program, and a family participation component. Wang's approach is consistent with reviews of work on instructional effectiveness by Brophy (1982), Rosenshine and Berliner (1978), and Rosenshine (1979), all of whom advocate a structured environment in which students are actively engaged in mastering correctly sequenced basic academic skills.

In contrast to Wang, who recommends pupil choice, Rouck's (1980) strategies, while centering on individualized assignments, suggest that low SES students learn more when activities are at a low level of complexity without pupil initiative. These suggestions are open to criticisms of stereotyping and oversimplification of curriculum for lowachieving, low-income children, which Meier (1984) claims is a recent trend among some educators.

\section{Multidimensional Classrooms}

Meier (1982) contends that schools should acknowledge a broad conception of human intelligence. Similarly, Rosenholtz and Wilson (1980) and Rosenholtz and Simpson (1984) stress the likely negative impact of "unidimensional classrooms" that narrowly define academic abilities and have a tendency to increase the amount of social stratification within them. By assigning uniform tasks in which peers can judge performance superiority, the effect is to produce inequality among students' perceptions of their own and others' abilities. Rosenholtz contends that students' feelings about school are closely associated with their academic ability levels and suggests that classrooms be organized in a multidimensional manner in which a number of attributes are valued and students select from a wide variety of tasks.
Judgments about performance superiority are more difficult and less likely as tasks become more varied.

Wang (1981) might concur with Rosenholtz's hypothesis, claiming that in a class with a wide continuum of academic and social learning goals, a student is less likely to develop perceptions of exception or failure. Jencks (1972), too, stresses the importance of diversity and choice. Roper and Roper (1979) suggest shifting more courses to an elective basis. Meier (1982) recommends that methods be used to stimulate curiosity and widen visions. Activities must be perceived as purposeful by the learner (Jencks, 1972). Hendricks (1981), in The Centered Teacher, suggests a variety of "nonacademic" activities, such as learning about feelings, building responsibility, and increasing self-awareness, to broaden the curriculum.

\section{Student Self-Management}

Students adept in self-management are able to discover independently how to use previously learned concepts to solve problems without much teacher assistance (Pines \& Julian, 1972). Wang and Lindvall (1984) claim that students' sense of personal control affects classroom behavior and the learning process. They believe that students' feelings can be modified through instructional intervention including students' opportunity to select activities from a choice of learning options. Wang (1976) emphasizes the importance of pupil choice in increasing the completion of work. Hollins (1982) suggests fostering leadership among pupils by encouraging children to think for themselves and take charge of their own destinies and helping students see the relationship between instructional content and personal aspirations.

\section{Individualized Incentives and Goal Structures}

Attribution theories postulate that students use information to arrive at causal ascriptions for outcomes primarily in terms of ability, effort, task difficulty, and luck (Weiner, 1979). Of these, effort is the only factor under students' volitional control amenable to change. If students believe that increased effort will result in success, they persist longer at a task and increase their level of performance. In contrast, individuals who find themselves unable to control aversive stimuli (i.e., negative evaluation) perceive themselves as helpless. Weiner maintains that classroom situational factors affect subsequent student behaviors (i.e., persistence, cognitions of success or failure, expectancies for future learning).

Under competitive conditions, Ames and Ames (1981) report, students perceive ability as a more salient cause of their successes or failures. They maintain that failing students are more self-punitive and perceive themselves as less 
capable of competition. On the other hand, a magnified positive affect is associated with success for successful students. Ames and Ames recommend individual goal-setting and contract learning in which students and teachers jointly develop plans to overcome learning obstacles, thus strengthening the effort/performance linkage and promoting realistic goal-setting and constructive interpretations of failure.

\section{Monitoring Pupil Progress}

Teachers in effective schools emphasize completion and mastery of curricular objectives. They also make efforts to monitor and assess students' academic progress (Brookover \& Lezotte, 1979).

\section{Personalized Grading}

Crain, Mahard, and Narot (1982) assert: "We subject children to a form of competitive grading which we would not tolerate for ourselves as adults. Public school is the last bastion of cutthroat competition. Teachers grade students, but they bitterly resist outside evaluation of their work" (p. 209). Block (1984) and Nicholls (1979) suggest that the motivational aspect of evaluation is more successful if it is based on task mastery rather than on social comparison. A task mastery grading strategy avoids the informational cues of single-dimensional judgments of relative ability found in social comparison (i.e., curve or normed) grading.

The grading done in special education classrooms often has been linked to personalized Individual Education Program goals and may be negotiated through teacher/pupil contracts. There is no reason why similar strategies cannot be implemented in regular heterogeneous classrooms. Personalized curriculum and grading are likely to result in experiences of school success for pupils which, in turn, are likely to result in a cycle of continuing academic achievement (i.e., prevention of the learned helplessness syndome) and vocational or career success (Gottfredson, 1980).

According to self-worth theory (Covington, 1984), success should cause feelings of high self-esteem, especially if students perceive their efforts and abilities to be responsible for their achievement, whereas failure causes a sense of worthlessness and social disapproval. Ornstein (1978) emphasizes the importance of minimizing failure situations and nurturing positive self-definitions. Cohen and Lazerson (1977) caution, however, that grades be based on objective criteria rather than subjectively based on personal characteristics.

\section{Maximizing Engaged Time}

Academic achievement depends on a high-powered academic emphasis in classrooms (Brophy, 1982). Instead of offering a worklike curriculum phrased in businesslike terminology ("time on task," "better products"), Block (1984) maintains that children prefer playlike, voluntary, personally meaningful activities. Children seem to better concentrate on these types of activities and feel more competent and in control in the classroom. Another method used to maximize engaged time is classwide peer tutoring (Reynolds \& Wang, 1983).

\section{Opportunity to Respond}

In a recent investigation, Stanley and Greenwood (1983) found that a high-achieving group had significantly more time for academic response than did low achievers, which those authors believe was caused by different instructional procedures used with the two levels. They suggest that instructional programs and teaching formats be designed to engage low-achievers in order to ameliorate below grade level achievement deficits. In setting goals for a comprehensive program for responsible citizenship, Brown (1977) emphasizes development of a value system compatible with principles underlying democratic institutions, as well as development of self-esteem to fully participate in civil life. A high level of student participation in class activities and opportunity to respond are correlated with achievement.

\section{Opportunity to Learn}

Of hundreds of variables surveyed, aside from home background, Walberg and Rasher (1979) found that opportunity to learn was most closely related to achievement. Opportunity to learn can include hours of instruction, hours of homework, cumulative years of study in the subject, and curricular emphasis and challenge. Brophy and Good (1974) found that teacher communication toward children from lower socioeconomic classes and racial and ethnic minority backgrounds is more likely to be aimed at controlling or managing behaviors, while communications to majority middle class children are more likely to be relevant to the content or skills of instruction. Although the results of expectancy studies vary considerably, Taylor (1979) found that teachers' interactions with their students in a lab situation varied with implanted expectations; more support, challenge, and encouragement were given to the high-expectations students. Clearly, interaction with minority children should be more instructionally oriented and should result in increased opportunity to learn.

\section{Continuity between Teaching and Learning Styles}

According to Edgerton (1981), "Because we know that subcultural differences can be important, we may be lulled into the belief that we have adequately taken them into 
account," but "our knowledge of subcultural factors is so inadequate that we can not have provided for differences" (p. 320). Witkin, Moore, Goodenough, and Cox (1977) maintain that when cognitive styles of students and teachers are matched, they view each other more positively and evaluations of students' performances are higher. Most school environments reflect a field-independent style (Cohen, 1969), characterized by an "analytic approach to a stimulus context that is reflected in the ability to restructure a perceptual field and extract the salient features from the embedded context" (Witkin et al., 1977, p. 3). In contrast, a field-dependent cognitive style is represented by a global mode of perception manifested by "the inability to separate part of a perceptual field from the field as a whole" (Witkin et al., 1977, p. 4).

Some minority groups have been described as field-dependent (i.e., blacks, by Shade, 1982; Mexican-Americans, by Cohen, 1969). School socialization or acculturation usually influences a transition from field-dependent to field-independent cognitive style (Berry, 1983). Field-independence is associated with Westernization. Although researchers in cognitive styles generally assume the position of cultural relativism, they search for systematic relationships among patterns of abilities and elements of cultural contexts (Berry, 1983). Nevertheless, success in mainstream school culture is associated with field-independent styles.

Secondary students classified as learning disabled often plateau at fourth or fifth grade, a level at which basic skill instruction ceases and students move on to a new level of cognitive functioning that requires integrating and applying what is learned (Sheinker, Sheinker, \& Stevens, 1984). Sheinker et al. maintain that academic achievement requires students to know how to learn rather than just what to learn. Gerber (1983), however, suggests that learning disabled students are not necessarily strategy-deficient (connoting absence of strategy use) but are strategy-inefficient or strategy-inflexible. Deliberately teaching cognitive strategies associated with improved academic performance has been recommended by Peterson and Swing (1982). They suggest that teachers can get information about effective learning strategies by questioning students about their thought processes at various times during instruction.

Using microethnography and context analysis, Mehan (1979) studied a class of low-income black and MexicanAmerican children in a school in San Diego. He concluded that classroom competence involves matters of form as well as content. Students must learn the appropriate form in which to cast their academic knowledge in school. Competent classroom membership involves employing interactional skills and abilities such as when, with whom, and where they can speak and act. Mehan distinguishes between general socialization, which he defines as the interactional and symbolic process involved in the transmission of general skills and abilities that everyone needs to know to be a competent member of a society, and formal education, which is concerned with the transmission of specialized skills, logical operations, and abstract systems.

Sullivan (1979) differentiates between structural and cultural assimilation, or acculturation. Structural assimilation requires the ability to deal with members of other groups in instrumental transactions and is necessary for success in school. Basically, students share with the school certain assumptions about schooling; however, they are able to maintain their ethnic or cultural uniqueness. In contrast, acculturation requires students to give up their cultural uniqueness.

There are different perspectives on acculturation. Those who take a cultural or cognitive deficit perspective would structure the school environment so as to modify the home or minority style. Those who adhere to a cultural relativity position, and who see cognitive variations as not only acceptable but valued, often recommend that teaching styles be adapted to accommodate minority learners who have unique styles. They believe that in a pluralistic, democratic society schools should go to the community to discern if a specific cultural identify is valued and desired or if acculturation and assimilation into the dominant culture is desired (Berry, 1983).

In an ethnographic study of a bicultural-bilingual classroom, Cazden, Carrasco, Maldonado-Guzman, \& Erickson observed that successful teachers matched their teaching with minority pupil styles and adapted their interaction to fit local customs. Cazden's conclusion was that effective bilingual/bicultural education resulted in better achievement, psychic well-being and adjustment to both worlds. Hollins (1982) wrote that Marva Collins's success in teaching innercity black children was attributable to the consistency between instructional style and interaction patterns commonly found in traditional black family settings, friendship groups, and religious settings.

American Indian children that Philips (1982) studied are enculturated in their preschool years into modes of organizing the transmission of verbal messages that are culturally different from those of Anglo middle-class children, she contends. The difference makes it difficult for them to comprehend verbal messages conveyed through schools' Anglo middle-class modes of organizing classroom interaction. Eventually Native American children don't participate verbally in classroom interactions because the social conditions for participation to which they have become accustomed in the Indian community are lacking. Philips calls the cultural differences "invisible" because school personnel working with the American Indian children do not notice them.

Saville-Troike (1978) summarizes the findings of a number of studies that have found that visual perception and visual memory of Native American children are higher 
than their Anglo age-mates. Sando (1973) analyzes how a difference in time orientation affects school performance: (1) It lowers attendance, particularly when school bus schedules are inflexible; (2) it is harder to command children's attention according to teacher-designed schedules; (3) it lowers scores on timed tests and assignments; and (4) American Indian children are unwilling to plan ahead. Sando claims, more generally, that the value structure of affluentoriented teachers alienates poor children. Their reaction is often social withdrawal in and from school.

Social withdrawal also has been observed by Wax, Diamond, and Gearing (1971), who report that the Sioux who do not conform to and adopt the Anglo culture of the school experience almost inevitably fail in school and are pushed out of school because of subcultural rather than academic reasons. Sioux children who do (marginally) succeed in school are characterized by their peers as lacking independent thought, spontaneity, and creativity-all highly prized Sioux traits. Dumont and Wax (1969) observed a nonresponsiveness in the reservation classroom, which was interpreted as the manner in which students protect themselves from cultural assault. Indians apparently see education as an Anglo intrusion. What is more, they find that the Cherokee do not believe that success in school will have an impact on the quality and character of their lives on the reservation.

Fuchs and Havighurst (1973) contend that American Indian children perceive their subordinate status and thus lose self-confidence and deny motivation for school success. Those authors found that only $11 \%$ of Bureau of Indian Affairs teachers were of Native American ancestry and the majority of teachers did not have a good understanding of, sensitivity to, and respect for the Indian community.

\section{Positive and Accepting Climate}

Contrary to the conclusions of the report on educational opportunity by Coleman and his colleagues (1969), there is evidence that certain classroom environments have a differential impact on various students and that they produce recognizable patterns of behavior (Forness, Guthrie, \& MacMillan, 1982). In England, Rutter, Maugham, Mortimore, and Ouston (1979) and Rutter (1983) found a significant effect of school on achievement test results in secondary schools. Even if a teacher/pupil style match is not possible, the creation of a warm, responsive climate in which diverse children are valued can be effective. Research indicates that low-income pupils are particularly sensitive to school climate (Spady, 1973).

Teacher socialization style has a powerful impact on children's social cognition and reported interpersonal classroom behavior, especially with younger children (Rohrkemper, 1984). Students appear to internalize the underlying princi- ples of their teacher's strategies for dealing with peers. Halperin (1976) also observes that teachers' goals and beliefs influence classroom activities, children's behaviors, and children's perceptions of school. Certain ideologies produce environments that children find anxiety-arousing.

According to Lightfoot (1983), "Good schools are places where students are seen as worthy of respect" (p. 350). Crain, Mahard, and Narot (1982) found that respect for students was influential in creating a positive school climate. Jencks (1972) suggested that school life be thought of as an end in itself. He observed that some schools are dull, depressing-even terrifying-places, while others are lively, comfortable, and reassuring. He recommended that children be offered diversity and choice and that schools be enjoyable, with children feeling that they are doing something purposeful.

Regarding social-psychological environments, Haertel, Walberg and Haertel (1979) conclude that learning gains are positively associated with student-perceived cohesiveness, satisfaction, task difficulty, formality, goal-directedness, and a good material environment, and negatively associated with frustration, cliques, apathy, and disorganization. Walberg and Rasher (1979) add that student involvement in school and student perceptions of democratic practices are also related to achievement.

\section{Acceptance of Child's Language}

Among the functions of language are those of serving as a symbol and identifier of group membership and as the principal medium for mediating and manipulating social relationships (Saville-Troike, 1980). Language is unique in its dual role as an intrinsic component of culture and as a medium through which other aspects of culture, including the content of formal education, are expressed and transmitted. Language is an intricate part of selfhood, and the way others respond to it affects the child's self-concept and feelings toward others.

Teachers' perceptions of limited-English proficient children or children with minority dialects are often negative. Teachers may categorically type the child without being sensitive to details of the language performance (Williams, 1976). Labov (1972) has written of the richness, fluency, and general competence of speakers of black English. Clearly, teachers should learn to appreciate language differences and make use of them creatively in the classroom.

\section{Increasing Tolerance for Diverse Students}

Regular class teachers tend to believe that the welfare of the larger group is their responsibility. Thus, among problem 
behaviors, disruptiveness, with the possibility of being "contagious" or having a ripple effect on other students' behaviors, is least acceptable because it is perceived as interfering with the general well-being of the group (Safran \& Safran, 1985). Teachers perhaps can be taught to broaden their range of tolerance for behavioral and academic differences (Oden, 1976). Through preservice or inservice training, they might also learn more effective behavior management strategies. A third possibility is to provide more classroom support or technical assistance in helping teachers deal with problematic behaviors.

Morton and Hull (1976) described a school where children simply were not referred for special education and the principal welcomed all. Mitman (1985) found that teachers who showed more concern for lower-achieving students tended to have more flexible and accurate perceptions of studentsbut unfortunately they were rated lower on their quality of teaching. Ferree (1985) believes that to know students, teachers must be able to put themselves in the student's place.

\section{Handicap Awareness}

Stevens and Allen (1984) summarize strategies for improving attitudes toward handicapped individuals. These include classroom instruction, role play (disability simulation), increased contact, media presentations, and social participation in structured social situations. Salend and Knops (1984) contend that some models tend to instill "wellmeaning but overly sympathetic" views toward handicapped people. They recommend a cognitive approach, whereby students learn about realistic classroom problems of handicapped students, to facilitate constructive, equal-status relationships.

\section{Dealing with Conflict}

According to Crain, Mahard, and Narot (1982), in desegregated settings "no open conflict is a bad sign" (p. 67). They, as well as Hilliard (1978) and Colemand (1978), advocate an open, communicative atmosphere where conflicts are brought into the open, discussed, and resolutions planned.

Liss and Robinson (1978) have described a number of specific methods for dealing with intergroup conflicts: (1) Sponsor student retreats with representatives from a variety of student groups; (2) conduct leadership training in racial/ ethnic awareness, understanding, and problem solving; (3) select committees of students to work toward problem resolution; (4) utilize faculty to seek solutions to racial strife; (5) have a separate disciplinary policy for dealing with racial incidents (they used a review board to hear cases involving alleged racial conflicts); (6) initiate a faculty/student human relations committee; (7) encourage "trouble-makers" to get involved with constructive solutions to the school's problems; and (8) provide more social and recreational activities in the school. Removing police from the school facilities was found to have a positive impact in the Liss and Robinson and the Crain, Mahard, and Narot situations.

\section{Parent/Community Involvement in Schools}

Walker and Perez (1980) emphasize the importance of local community schools in enhancing parental attitudes toward schools. They suggest that the school be a catalytic agent by providing leadership to mobilize community resources to solve identified community problems. Although Walker and Perez prefer small schools because they reduce anonymity and invite alliances between urban schools and the community, other sources have suggested creating longterm subgroups of students or within-school clusters, to involve students and give them a sense of belonging and being known in school (Crain, Mahard, \& Narot, 1982). The consensus is that attempts should be made to actively involve parents in schools. Walberg (1984) distinguishes various roles for family partnerships in schooling: audience for child's work, home tutor, co-learner, supporter of school programs, advocate before school board and other officials, committee members, and paid school workers.

\section{Conscious Involvement of Diverse Children}

Steps should be taken to involve mainstreamed handicapped students in the daily routine; otherwise they are unlikely to become accepted members of the regular class (Gottlieb \& Leyser, 1981). Gresham (1982), too, claims that benefits do not occur with mainstreaming unless active programmatic interventions are implemented.

\section{Social Skills Training}

Maheady, Maitland, and Sainato (1984) report that mildly mentally handicapped children engage in behavior associated with social perception deficits more often than their nondisabled peers do. Gresham (1982), too, argues that mainstreaming efforts do not increase social interaction with most handicapped students because they lack the social skills needed to interact with their peers. Elias and Maher (1983) report that their television-based instructional format for teaching social-cognition, problem-solving skills is valuable in teaching social skills.

Peer tutoring has been advocated as an effective technique for improving social adjustment. The technique used by Custer and Osguthorpe (1983) was unique: having handicapped students tutor their nonhandicapped peers in sign lan- 
guage for 8 weeks-which gave the handicapped students a superior social advantage. They found that social interaction between handicapped and nonhandicapped individuals during free time rose from $5 \%$ to $46 \%$, and nonhandicapped students reported that the handicapped were "fun to be with." Powell and Lindeman (1983) utilized "free play" periods to teach social interaction skills. They suggest that teachers prompt, model, and physically assist handicapped children to share, assist peers, and initiate and maintain an activity. Dodge (1983) and Odom and McConnell (1985) report success in studies of different strategies for promoting social competence in children with social problems to increase and improve social relations.

\section{Grouping Strategies}

Allport (1954) suggests that common goals be held for all students and that a cooperative atmosphere is conducive to positive peer interaction. A multitude of studies about cooperative grouping arrangements have been conducted of late. Although there are a variety of models for cooperative grouping, they all seem to involve some form of heterogeneous pupil grouping (variety of ability or achievement levels, handicapped and nonhandicapped, members of different races and ethnic groups, males and females) that works together toward a common goal.

Cooperative grouping can be as simple as peer tutoring or as complex as a group investigation with individualized assignments. For example, Aronson, Blaney, Stephen, Sikes, \& Snapp (1978) developed a "Jigsaw Classroom," involving five- to six-member groups in which each member is assigned a portion of the total assignment, masters that material, and then teaches the group. Thus, students depend on each other for the total picture. After 6 weeks of use, those authors claimed students: (1) had a stronger liking of peers, (2) believed they could learn from classmates, (3) liked school better, (4) had more positive self-concepts, (5) improved academically, and (6) showed improved racial behavior.

In comparison with competitive or individualistic arrangements, a number of reviews have concluded that cooperative learning techniques can achieve both cognitive and affective goals (Johnson, Maruyama, Johnson, Nelson, \& Skon, 1981; Sharan, 1980; Slavin, 1980). Team learning can have a positive effect on motivation (Slavin \& Karweit, 1984) and self-concept of ability (Ames, 1981). It also promotes cross-handicap interaction during instruction and during post-instruction free time (Johnson \& Johnson, 1981), has a positive impact on race relations (DeVries \& Slavin, 1976; Slavin \& Madden, 1979), promotes cross-sex and crossethnic relationships (Warring, Johnson, Maruyama, \& Johnson, 1985), and creates favorable attitudes toward school and academic success.
Cooperative grouping arrangements can create a sense of mutual concern and group membership (DeVries \& Slavin, 1976; Slavin, 1980), improve student perceptions of degree of cooperation in their learning environment (Talmadge \& Pascarella, 1984), increase the accuracy of daily work and post-instructional retention (Yager, Johnson, \& Johnson, 1985), and improve reading achievement (Talmadge \& Pascarella, 1984). Combined with individualized instruction (i.e., in the Team Assisted Instruction program), cooperative grouping can increase mathematics achievement (Slavin \& Karweit, 1984). Slavin (1984) emphasizes that student achievement in the use of cooperative methods results from the use of cooperative incentives, not cooperative tasks.

\section{Teacher Characteristics}

Rosenholtz (1985) emphasizes the importance of recruiting outstanding teachers, monitoring their actions, and supplying technical assistance, to improve student achievement in inner-city schools. Others contend that teachers of diverse groups of children must value different types of people (Love, 1977), have positive expectations for all children (Dotts, 1975), and encourage all children to excel (Love, 1977).

These teachers must be dedicated to the principles of integrated education (Brazziel, 1978) and be advocates for low-income and minority children (Fuchs, 1973). They need to eradicate residual prejudice from their language (Hilliard, 1978). Gallagher (1985) and Baum and Frazita (1979), among others, have documented positive changes in teacher attitude toward mainstreaming following training.

\section{Leadership}

An Educational Testing Service (1976) study of 118 elementary and 93 high schools concluded that good race relations among students resulted at schools where both black and white teachers gave principals high ratings as "supportive." In aggregating the results of approximately 1,200 studies of urban schools, Clark, Lotto, and McCarthy (1980) rank leadership-particularly that of school principals-and teacher attitudes toward education and the expected success of educational programs at the top of their list. Walter (1981) calls for vigorous leadership at all levels, and administrators who are well-versed in program content and who give feedback effectively. Further, he contends that administrators must be willing to take risks, or make changes in the face of substantial opposition, and articulate and implement policies that have new programs, role changes, and different organization. Walter believes that effective implementation requires time, personal interaction and contacts, inservice training, and people-based support. 


\section{CONCLUSION}

Serow and Solomon (1979) found a majority of parents to be in favor of racial desegregation. In interviews with low-income parents, Brantlinger (1985b) found that the majority preferred social-class integrated schools for their children. A multitude of writers (e.g., Gardner, 1982; Moran, 1984; Oden, 1976; Strang, Smith, \& Rogers, 1978) emphasize the potential benefits of mainstreaming for mildly handicapped children. But simply desegregating diverse populations without adopting effective methods of teaching them can have a negative impact on the minority student.

\section{REFERENCES}

Aquirre, A. (1979). Chicanos, intelligence testing and the quality of life. Educational Research Quarterly, 4, 3-12.

Algozzine, B., Ysseldyke, J.E., \& Christenson, S. (1983). The masses are burgeoning. Journal of Special Education, 17(2), 141-146.

Allport, G. (1954). The nature of prejudice. Reading, MA: Addison-Wesley.

Ames, C. (1981). Competitive versus cooperative reward structures: The influence of individual and group performance factors on achievement attributions and affect. American Educational Research Journal, 18, 273287.

Ames, C., \& Ames, R. (1981). Competitive versus individualistic goal structures: The salience of past performance information for causal attributions and affect. Journal of Educational Psychology, 73, 411-418.

Anderson, G.R., \& Anderson, S.K. (1983). The exceptional native American. In D.R. Omark \& J.G. Erickson (Eds.), The bilingual exceptional child (pp. 163-180). San Diego: College-Hill Press.

Anyon, J. (1980). Social class and the hidden curriculum of work. Journal of Education, 62, 67-92.

Apple, M. (1982). Education and power. Boston: Routledge/Kegan Paul.

Argulewicz, E.N. (1983). Effects of ethnic membership, socioeconomic status, and home language on LD, EMR, and EH placements. Learning Disabilities Quarterly, 6, 195-200.

Aronson, E., Blaney, N., Stephen, C., Sikes, J., \& Snapp, M. (1978). The jigsaw classroom. Beverly Hills, CA: Sage Publications.

Baum, R.B., \& Frazita, R.F. (1979). Educating the exceptional child in the regular classroom. Journal of Teacher Education, 30(6), 20-21.

Berman, E.H. (1984). State hegemony and the schooling process. Journal of Education, 166(3), 239-253.

Bernal, E.M. (1983). Trends in bilingual special education. Learning Disabilities Quarterly, 6, 424-431.

Berry, J.W. (1983). Comparative studies of cognitive styles. In R.J. Samuda \& S.L. Woods, Perspectives in immigrant and minority education (pp. 247-257). Lanham, MD: University Press of America.

Block, J.H. (1984). Making school learning activities more playlike: Flow and mastery learning. Elementary School Journal, 85(1), 64-75.

Bowles, S., \& Gintis, H. (1976). Schooling in capitalist America. New York: Basic Books.

Brantlinger, E.A. (1985a). Low-income parents' perceptions of favoritism in the schools. Urban Education, 20(1), 82-102.

Brantlinger, E.A. (1985b). Low-income parents' opinions about the social class composition of schools. American Journal of Education, 93(3), 389-408.

Brazziel, W. (1978). Quality integrated education. Theory Into Practice, $17(2), 93$.

Broman, S.H., Nichols, P.L., \& Kennedy, W.A. (1975). Preschool IQ: Prenatal and early developmental correlates. Hillsdale, NJ: Erlbaum Press.

Brookover, W.B., \& Lezotte, L. (1979). Changes in school characteristics coincident with changes in student achievement. East Lansing: Michigan State University, Institute for Research in Teaching.

Brophy, J. (1982). Successful teaching strategies for the inner-city child. Phi Delta Kappan, 63, 527-530.
Brophy, J.E., \& Good, T. (1974). Teacher-student relationships: Causes and consequences. New York: Holt, Rinehart \& Winston.

Brown, B.F. (1977). Education for responsible citizenship (Report) Washington, DC: National Task Force on Citizenship Education.

Burnett, J.H. (1976). Commentary: Paradoxes and dilemmas. Anthropology \& Education Quarterly, 7, 37-38.

Cazden, C.B., Carrasco, R., Maldonado-Guzman, A.A., \& Erickson, F. (1980). The contribution of ethnographic research to bicultural-bilingual education. In J.E. Alatis (Ed.), Current issues in bilingual education (pp. 64-80). Washington, DC: Georgetown University Press.

Clark, D.L., Lotto, L.S., \& McCarthy, M.M. (1980). Factors asssociated with success in urban elementary schools. Phi Delta Kappan, 61, 467-470.

Cohen, D., \& Lazerson, M. (1977). Education and the corporate order: Merit and equality. In J. Karabel \& A.H. Halsey (Eds.), Power and ideology in education. New York: Oxford University Press.

Cohen, R.A. (1969). Conceptual styles, cultural conflict and nonverbal tests of intelligence. American Anthropologist, 71, 828-856.

Coleman, J.M. (1978). The intergroups relations specialist: Change agent for public schools. Theory Into Practice, 17(2).

Coleman, J.S., et al. (1969). Equal educational opportunity. Cambridge, MA: Harvard University Press.

Covington, M.V. (1984). The self-worth theory of achievement motivation: Findings and implications. Elementary School Journal, 85(1), 4-20.

Crain, R.L., Mahard, R.E., \& Narot, R.E. (1982). Making desegregation work: How schools create social climates. Cambridge, MA: Ballinger Publishing Co.

Crosland, C.A.R. (1974). Comprehensive education. In Socialism now and other essays (pp. 193-210). London: Cape Press.

Custer, J.D., \& Osguthorpe, R.T. (1983). Improving social acceptance by training handicapped students to tutor their nonhandicapped peers. Exceptional Children, 50(2), 173-174.

DeVries, D.L., \& Slavin, R.E. (1976). Teams-games tournament: A final report on the research. Baltimore: Center for Social Organization of Schools, Johns Hopkins University.

Dodge, K.A. (1983). Promoting social competence in school children. Schools \& Teaching, 1(2).

Dotts, W. (1975). Black and white teacher attitude toward disadvantage and poverty. Education, 99, 48-54.

Drummond, H. (1982). Power, madness and poverty. Behavior Disorders, 7, 101-109.

Dumont, R., Jr., \& Wax, M.L. (1969). Cherokee school society and the intercultural classroom. Human Organization, 28, 217-226.

Edgerton, R.B. (1981). Another look at culture and mental retardation. In M.J. Begab, H.C. Haywood, \& H.L. Garber, Psychosocial influences in retarded performance (Vol. 1) (pp. 309-323). Baltimore: University Park Press.

Educational Testing Service. (1976). Conditions and processes of effective desegregation. Princeton, NJ: Educational Testing Service.

Educational Testing Service. (1980). New vistas in special education. Focus, 8, 1-20.

Elias, M.J., \& Maher, C.A. (1983). Social and affective development of children: A programmatic perspective. Exceptional Children, 49(4), 339-344.

Ferree, G. (1985). The epistemology of knowing how students feel. American Journal of Education, 93(2), 240-251.

Ford, J., Mongon, D., \& Whelan, M. (1982). Special education and social control: Invisible disaster. London: Routledge/Kegan Paul.

Forness, S.R., Guthrie, D., \& MacMillan, D.L. (1982). Classroom environments as they relate to mentally retarded children's observable behavior. American Journal of Mental Deficiency, 87(3), 259-265.

Fuchs, E. (1973). How teachers learn to help children fail. In N. Keddie (Ed.), The myth of cultural deprivation (pp. 75-85). London: Penguin Education.

Fuchs, E., \& Havighurst, R.J. (1973). To live on this earth. New York: Anchor/Doubleday.

Gallagher, P. (1985). Inservice: A mandated special education course and its effects on regular classroom teachers. Teacher Education \& Special Education. 8(2), 59-65.

Gardner, W.I. (1982). Why do we persist? Education \& Treatment of Children, 5, 369-378. 
Gerber, M.M. (1984). Learning disabilities and cognitive strategies: A case for training or constraining problem solving? Journal of Learning Disabilities, 16(5), 255-260.

Giroux, H.A. (1983). Theories of reproduction and resistance in the new sociology of education: A critical analysis. Harvard Educational Review, 53, 257-293.

Glass, G.V. (1980). On criticism of our class size/student achievement research. Phi Delta Kappan, 62, 242-244.

Gordon, M.T. (1976). A different view of the IQ-achievement gap. Sociology of Education, 49, 4-11.

Gottfredson, G.D. (1980). Schooling and delinquency prevention: Some practical ideas for educators, parents, program developers and researchers (Report Number 303). Baltimore: Johns Hopkins University Center for Social Organization of Schools.

Gottlieb, J. (1982). Mainstreaming. Education \& Training of the Mentally Retarded, 17, 79-82.

Gottlieb, J., \& Leyser, Y. (1981). Facilitating the social mainstreaming of retarded children. Exceptional Education Quarterly, l(4), 57-69.

Gresham, F.M. (1982). Misguided mainstreaming: The case for social skills training with handicapped children. Exceptional Children, 48, 422-435.

Haertel, G.D., Walberg, H.J., \& Haertel, E.H. (1979, April). Sociopsychological environments and learning: $A$ quantitative synthesis. Paper presented at the annual meeting of the American Educational Research Association, San Francisco.

Halperin, M.S. (1976). First grade teachers' goals and children's developing perceptions of school. Journal of Educational Psychology, 68, 636-648.

Harris, J.J., III (1978). Impact of desegregation: A historical and legal analysis. In F. Aquila (Ed.), School desegregation: A model at work (pp. 53-68). Bloomington, IN: Training Institute, School of Education.

Hendricks, G. (1981). The centered teacher: Awareness activities for teachers and their students. New Jersey: Prentice-Hall.

Hilliard, A.G., III. (1978). Straight talk about school desegregation problems. Theory Into Practice, 17(2), 100-106.

Hollins, E.R. (1982). The Marva Collins story revisited: Implications for regular classroom instruction. Journal of Teacher Education, 33(1).

Jencks, C. (1972). Inequality, a reassessment of the effect of family and schooling in America. New York: Harper \& Row.

Johnson, D.W., Maruyama, G., Johnson, R., Nelson, D., \& Skon, L. (1981). Effects of cooperative, competitive and individualistic goal structures on achievement: A meta-analysis. Psychological Bulletin, $89(1), 47-62$.

Johnson, R.T., \& Johnson, D.W. (1981). Building friendships between handicapped and non-handicapped students: Effects of cooperative and individualistic instruction. American Educational Research Journal, I8, 415-423.

Jones, R.L., \& Wilderson, F.B., Jr. (1976). Mainstreaming and the minority child: An overview of issues and a perspective. In R.L. Jones (Ed.), Mainstreaming and the minority child (pp. 1-13), Reston, VA: Council for Exceptional Children.

Kushlick, A., \& Blunder, R. (1974). The epidemiology of mental subnormality. In A.M. Clark \& A.B. Clarke (Eds.), Mental deficiency: The changing outlook (3rd ed.). New York: Free Press.

Labov, W. (1972). Language in the inner city: Studies in Black English vernacular. Philadelphia: University of Pennsylvania Press.

Levine, D.U., Kukuk, C., \& Meyer, J.K. (1979). Poverty in big cities. In H.J. Walberg (Ed.), Educational environments and effects. Berkeley: McCutchan Publishing Corp.

Lightfoot, S.L. (1983). The good high school: Portraits of character and culture. New York: Basic Books.

Liss, M., \& Robinson, J.C. (1978). The Carteret story: The peer group deals with racial conflict. Phi Delta Kappan, 57, 169-172.

Longo, P. (1982). Mainstreaming: The promise and the pitfalls. Urban Education, 17, 157-180.

Lorde, A. (1983). There is no hierarchy of oppressions. Interracial Books for Children, 14(3\&4), 9.

Love, B.J. (1977). Desegregation in your school: Behavior patterns that get in the way. Phi Delta Kappan, 56, 168-170.

MacMillan, D.L. (1976). Mental retardation in school and society. Boston: Little, Brown.
Madden, N., \& Slavin, R.E. (1983). Mainstreaming students with mild handicaps: Academic and social outcomes. Review of Educational Research, 53, 519-569.

Maheady, L., Maitland, G. \& Sainato, D. (1984). The interpretation of social interactions by mildly handicapped and non-disabled children. Journal of Special Education, 18(2), 151-159.

McKnight, R.T. (1982). The learning disability myth in American education. Journal of Education, 164(4), 351-359.

Mare, R.D. (1981). Change and stability in educational stratification. American Sociological Review, 46, 72-87.

Mehan, H. (1979). Learning lessons: Social organization in the classroom. Cambridge: Harvard University Press.

Meier, D. (1982). Planning to keep them in their place. In These Times, May 26.

Meier, D. (1984, Winter). "Getting tough" in the schools. Dissent, pp. $61-70$.

Mitman, A.L. (1985). Teachers' differential behavior toward higher and lower achieving students and its relation to selected teacher characteristics. Journal of Educational Psychology, 77(2), 149-161.

Moran, M.R. (1984). Excellence at the cost of instructional equity: The potential impact of recommended reforms upon low achieving students. Focus on Exceptional Children, 16(7), 1-12.

Morton, K.A., \& Hull, K. (1976). Parents and the mainstream. In R.L. Jones (Ed.), Mainstreaming and the minority child (pp. 37-52). Reston, VA: Council for Exceptional Children.

Nicholls, J.G. (1979). Quality and equality in intellectual development: The role of motivation in education. American Psychologist, 34, 10711084.

Ochoa, A.M., Pacheco, R., \& Omark, D.R. (1983). Addressing the learning disability needs of limited-English proficient students: Beyond language and race issues. Learning Disabilities Quarterly, 6, 416-423.

Oden, C.W., Jr. (1976). Desegregation and mainstreaming: A case of deja vu. In R.L. Jones, Mainstreaming and the minority child (pp. 53-64). Reston, VA: Council for Exceptional Children.

Odom, S.L., \& McConnell, S.R. A performance-based conceptualization of social competence of handicapped preschool children: Implications for assessment. Topics in Early Childhood Special Education, 4(4), $1-19$.

Ogbu, J.U. (1974). The next generation: An ethnography of an urban neighborhood. New York: Academic Press.

Orfield, G. (1978). Must we bus? Segregated schools and national policy. Washington, DC: Brookings Institute.

Ornstein, A.C. (1978). Education and social inquiry. Itasca, IL: F.E. Peacock Publishers.

Patchen, M. (1982). Black-white contact in schools: Its social and academic effects. West Lafayette, IN: Purdue University Press.

Peterson, P., \& Swing, S. (1982). Beyond time on task: Students' reports of their thought processes during classroom instruction. Elementary School Journal, 82, 481-491.

Philips, S.U. (1982). The invisible culture: Communication in classroom and community on the Work Springs Indian Reservation. New York: Longman Press.

Pines, H.A., \& Julian, J.W. (1972). Effects of task and social demands on locus of control differences in information processing. Journal of Personality, 40, 407-416.

Pink, W.T. (1982). School effects, academic performance, and school crime. Urban Education, 17, 51-72.

Polloway, E.A. (1984). The integration of mildly retarded students in the schools: A historical review. Remedial \& Special Education, 5(4), 18-28.

Polloway, E.A., \& Smith, J.D. (1983). Changes in mild mental retardation: Population, programs, and perspectives. Exceptional Children, 50, 149159.

Powell, T.H., \& Lindeman, D.P. (1983). Developing a social interaction teaching program for young handicapped children. Exceptional Children, 50(1), 72-74.

Ramey, C.T., \& Campbell, F.A. (1979). Compensatory education for disadvantaged children. School Review, 87, 1711-1789.

Reynolds, M.C., \& Wang, M.C. (1983). Restructuring "special" school programs. Policy Studies Review, 2(1), 189-212. 
Rist, R.C. (Ed.) (1979). Desegregated schools: Appraisals of an American experience. New York: Academic Press.

Rohrkemper, M.M. (1984). The influence of teacher socialization style on students' social cognition and reported interpersonal classrom behavior. Elementary School Journal, 85(2), 244-275.

Roper, D., \& Roper, S. (1979). The accountable school: Elective courses, competition and cost effectiveness. Phi Delta Kappan, 62, 527-528.

Rosenholtz, S.J. (1985). Effective schools: Interpreting the evidence. American Journal of Education, 93(3), 352-388.

Rosenholtz, S.J., \& Simpson, C. (1984). Classroom organization and student stratification. Elementary School Journal, 85(1), 21-37.

Rosenholtz, S., \& Wilson, B. (1980). The effect of classroom structure on shared perceptions of ability. American Educational Research Journal, 17, 75-82.

Rosenshine, B.V., \& Berliner, D.C. (1978). Academic engaged time. British Journal of Teacher Education, 4, 3-16.

Rosenshine, B.V. (1979). Content, time and direct instruction. In P. Peterson \& H. Walberg (Eds.), Research on teaching: Concepts, findings and implications (pp. 28-56). Berkeley: McCutchan Press.

Rouck, U. (1980). What makes an effective teacher? Research confirms the complexity of the teacher's job. American Educator, 4(3), 14-17.

Rutter, M. (1983). School effects on pupil progress: Research findings and policy implications. Child Development, 54, 1-29.

Rutter, M., Maugham, B., Mortimore, P., \& Ouston, J. (1979). Fifteen thousand hours: Secondary schools and their effect on children. Cambridge, MA: Harvard University Press.

Safran, S.P., \& Safran, J.S. (1985). Classroom context and teachers' perceptions of problem behaviors. Journal of Educational Psychology, 77(1), 20-28.

St. John, N. (1975). School desegregation: Outcomes for children. New York: John Wiley \& Sons.

Salend, S.J., \& Knops, B. (1984). Hypothetical examples: A cognitive approach to changing attitudes toward the handicapped. Elementary School Journal, 85, 228-235.

Sando, J. (1973). Educating the native American: Confict in values. In L. Branford, L. Baca, \& K. Lane, Cultural diversity and the exceptional child (pp. 58-65). Reston, VA: Council for Exceptional Children.

Saville-Troike, M. (1978). A guide to culture in the classroom. Roslyn, VA: National Clearing House for Bilingual Education.

Saville-Troike, M. (1980). Cross-cultural communications in the classroom. In J.E. Alatis, (Ed.), Current issues in bilingual education. Washington, DC: Georgetown University Press.

Schofield, J.W. (1982). Black and white in school: Trust, tension or tolerance? New York: Praeger Publishers.

Serow, R.C., \& Solomon, D. (1979, June). Parents' attitudes toward desegregation: The proximity hypothesis. Phi Delta Kappan, pp. $752-$ 753.

Shade, B.J. (1982). Afro-American cognitive style: A variable in school success? Review of Educational Research, 52, 219-244.

Sharan, S. (1980). Cooperative learning in small groups: Recent methods and effects on achievement, attitudes and ethnic relations. Review of Educational Research, 50(2), 241-271.

Sheinker, A., Sheinker, J.M., \& Stevens, L.J. (1984). Cognitive strategies for teaching the mildly handicapped. Focus on Exceptional Children, $17(1), 1-15$.

Seiber, R.T. (1982). The politics of middle-class success in an inner-city public school. Journal of Education, 164, 30-47.

Singleton, J. (1974). Implications of education as culture transmission. In G. Spindler (Ed.), Education and cultural process: Toward an anthropology of education. New York: Holt, Rinehart, \& Winston.

Slavin, R.E. (1980). Cooperative learning. Review of Educational Research, 50(2), 315-342.

Slavin, R.E. (1984). Students motivating students to excel: Cooperative incentives, cooperative tasks, and student achievement. Elementary School Journal, 85(1), 53-63.

Slavin, R.E., \& Karweit, N.L. (1984). Mastery learning and student teams: A factorial experiment in urban general mathematics classes. American Educational Research Journal, 21(4), 725-736.

Slavin, R.E., \& Madden, N.A. (1979). School practices that improve race relations. American Educational Research Journal, 16, 169-180.
Smith, B. (1983). Homophobia: Why bring it up? Interracial Books for Children, $14(2$ \& 4), 7-8.

Spady, W.G. (1973). The impact of school resources on students. In F. Kerlinger (Ed.), Review of Research in Education (Vol. 1). Itasca, IL: F.E. Peacock Publishers.

Stanley, S.O., \& Greenwood, C.R. (1983). How much "opportunity to respond" does the minority disadvantaged student receive in school? Exceptional Children, 49(4), 370-373.

Stevens, R.N., \& Allen, R.F. (1984). Strategies for improving attitudes toward handicapped students. Social Studies, 75, 220-223.

Strang, L., Smith, M.D., \& Rogers, C.M. (1978). Social comparison, multiple reference groups and the self-concept of handicapped children before and after mainstreaming. Journal of Educational Psychology, $70,487-497$.

Sullivan, M.L. (1979). Desegregation in a polyethnic New York City high school. In R.C. Rist (Ed.), Desegregated schools: Appraisals of an American experience (pp. 201-240). New York: Academic Press.

Talmage, H., \& Pascarella, E.T. (1984). The influence of cooperative learning-strategies on teacher practices, student perceptions of the learning environment and academic achievement. American Educational Research Journal, 12(1), 163-179.

Taylor, M.C. (1979). Race, sex and the expression of self-fulfilling prophecies in a laboratory teaching situation. Journal of Personality \& Social Psychology, 37, 897-912.

Tinney, J.S. (1983). Interconnections. Interracial Books for Children, $14(3 \& 4), 4-6+$

Walberg, H.J. (1984). Families as partners in educational productivity. Phi Delta Kappan, 65(6), 397-400.

Walberg, H.J., \& Rasher, S.P. (1979). Achievement in fifty states. In H.J. Walberg (Ed.), Educational environments and effects (pp. 353368). Berkeley: McCutchan Publishing Corp.

Walker, J.E., \& Peréz, R.L. (1980). Improving public confidence in education. Clearing House, 53, 394-396.

Walter, J.E. (1981). Successful program implementation in urban schools. Educational Leadership, 38, 635-638.

Wang, M.C. (1976). Maximizing the effective use of school time by teachers and students. Pittsburgh: Learning Research \& Development Center, University of Pittsburgh.

Wang, M.C. (1981). Mainstreaming exceptional children: Some instructional design and implementation considerations. Elementary School Journal, 81, 194-221.

Wang, M.C., \& Lindvall, C.M. (1984). Individual differences and school learning environments. In E.W. Gordon (Ed.), Review of research in education (Vol. 2). Washington, DC: American Educational Research Association.

Warring, D., Johnson, D.W., Maruyama, G., \& Johnson, R. (1985). Impact of different types of cooperative learning on cross-ethnic and cross-sex relationships. Journal of Educational Psychology, 77(1), 5359.

Wax, M.L., Diamond, S., \& Gearing, F.O. (Eds.). (1971). Anthropological perspectives on education. New York: Basic Books.

Weiner, B. (1979). A theory of motivation for some classroom experiences. Journal of Educational Psychology, 71, 3-25.

Williams, F. (1976). Explorations of the linguistic attitudes of teachers. Rowley, MA: Newbury House.

Witkin, H.A., Moore, C.A., Goodenough, D.R., \& Cox, P.W. (1977). Field-dependent and field-independent cognitive styles and their educational implications. Review of Educational Research, 47, 1-64.

Wright, P., \& Santa Cruz, R. (1983). Ethnic composition of special education programs in California. Learning Disabilities Quarterly, 6, 387394.

Yager, S., Johnson, D.W., \& Johnson, R.T. (1985). Oral discussion, group-to-individual transfer, and achievement in cooperative learning groups. Journal of Educational Psychology, 77(1).

Ysseldyke, J.E., Algozzine, B., \& Richey, L. (1982). Judgment under uncertainty: How many children are handicapped? Exceptional Children, 48 . 